\title{
USTERIA Willdenow versus USTERIA Medikus
}

\section{A. J. M. Leeuwenberg (Wageningen) and F. A. Stafleu (Utrecht)}

The name Usteria was published twice in the year 1790 for entirely different plants: Medikus used it for a new liliaceous genus, often reduced to Scilla L., but now usually regarded as distinct under the name Endymion, whereas Willdenow used it for a new genus of Loganiaceae. The Willdenow name has hitherto been in continuous use and it is therefore of some importance to know whether or not it has priority over the Medikus name. The publications are as follows:

Usteria Willdenow in Cothenius, Disp. 1. 1790 (Jan-Mai); Willdenow, Schr. Berlin. Ges. Naturf. Fr. 10: 51. 1790 (Jun-Aug) (T.: U. guineensis Willdenow).

Monodynamis J. F. Gmelin, Syst. 2: 10. Nov 1791 (T.: M. iserti J. F. Gmelin, nom. illeg.).

Usleria Medikus, Acta Acad. Theod. Palat. Phys. 6: 480.1790 (Mar-Mai) (T.: U. hyacinthiflora Medikus).

Cothenius' Dispositio Vegetabilium methodica a staminum numero desumta was published posthumously; Cothenius died, according to Pritzel (Thesaurus p. 70) and the Allgemeine deutsche Biographie (4: 517. 1876), on 5 January 1789 [sic]. Before his book was published, references were added to several names which had been published later in the year 1789 (e.g. on p. 19, sub 135, Quivisia Cavanilles, Diss. 7: 367. Apr 1789, and on p. 28, sub 216 ' 'Hoffmanna [sic] Willdenow' in Römer et Usteri, Bot. Mag. 6: 15 published in the second half of 1789). We presume that the anonymous hand who took care of all this was that of Willdenow although we have no proof of this.

Cothenius' publication is dated 1790 , but no indication of a more precise date has been found by us in the volume. The latest names mentioned date from the second half of 1789. On the other hand we know for certain that the book was out on 28 September 1790 because at that date Willdenow sent a copy of it to Banks (letter 
at British Museum, Add. Ms 8097. 357, kindly consulted for us by Mr R. Ross) together with copies of his Historia Amaranthorum 1790 and his edition of Linnaeus' Philosophia botanica (Soulsby 449). The Dispositio was not mentioned, alas, in the 1790 or 1791 volumes of the Göttingische Anzeigen von gelehrten Sachen, but it was reviewed in the Magazin für die Botanik, edited by J. J. Römer and P. Usteri, 10: 144 (1790). The copy for this 10th volume ("Stück") was very probably prepared before 3 June 1790 , this being the latest and last date in the volume mentioned, on p. 200 . We realize that this is not direct proof, but the nature of the contents of volume 10 is such that we think it highly probable that the copy for it was ready by 3 June. This would mean that Cothenius' book had been received in Zürich by that date. We have no further data on the publication of the Magazin vol. 10. It was reviewed by the Allgemeine Literatur-Zeitung only on 21 April 1791 1791(2): 143. 21 Apr 1791), together with volumes 11 and 12. The rather meagre result of all this is therefore that the Dispositio was published in all probability between January and May 1790.

The date of tomus VI, pars physica, of the Acta Academiae Theodoro-Palatinae cannot be established with any more precision than that of the Dispositio. It was reviewed in the same 10th "Stück" of the Magazin für die Botanik, which leads us to the conclusion that this book too must have been received at Zürich by 3 June 1790. Further proof of this is found in a review in the Gött. gelehrte Anz. 1790: 1017 on 26 June 1790. The review in the Allgemeine Literatur-Zeitung was published on 6 November $[1790(4): 345$. 6 Nov 1790]. In the book itself we find a note, dated 9 March 1790 stating that Medikus received a certain book at that date when the volume was "beinah im drucke geendigt". This means that volume 6 of the Acta, which was evidently published as a whole, appeared at any rate later than 9 March, and before 3 June 1790.

The first part of the 10th volume of the "Schriften der Berlinischen Gesellschaft Naturforschender Freunde", was reviewed in the Gött. gelehrte Anz. 1790(2): 1332 on 21 Aug 1790, so considerably later than the two other books. In it the reviewer remarks that the name Usteria Willdenow had already been used ("ein [sic] Name, den ein anderer Freund des Hrn. D. [Willdenow] bereits einer bisher zu den Hyacinthen gezählten Pflanze beygelegt hat"). Since Medikus' publication had been reviewed by the same journal on 26 June 1790 , it is obvious that reference is made here to that publication. The Dispositio by Cothenius had not been reviewed by the Gött. gelehrte Anz. Although we have no further proof it seems to us that we may assume on the ground of the later review that this volume of the Schriften was published after the two other books in question, so after May and before 21 August 1790. Willdenow makes no reference here to his earlier publication in Cothenius.

With this scanty information we have to take a decision on the question which of the two Usteria's has priority over the other. It is still possible that other information will come forward, but in the absence of more precise details we have to work with those given above. One would be inclined to say that there is a reasonable chance that Cothenius (Jan-Mai 1790, manuscript finished in 1789) was just a little earlier than Medikus (Mar-Mai, manuscript closed Mar 1790), but that is about all. In such a case we think that we are entitled to make a choice retaining $U_{\text {steria }}$ Willdenow 1790 and to reject Usteria Medikus as a later homonym.

Usteria Willdenow has been in continuous use since its publication. Usteria Medikus has never been taken up again as far as we know. The name Monodynamis Gmelin was a substitute for Usteria Willdenow but Gmelin gives no reasons for this change, and he ignores the Medikus name. It cannot be said therefore that Gmelin made a choice or that he probably had further information. Monodynamis has not been used 
again, as far as we know, except by Poiret (Dict. Sc. Nat. 32: 476. 1824). Since it is also very unlikely that the Willdenow and Medikus names were published simultaneously (on the contrary: the indications we have point to priority for the Dispositio) we cannot invoke Art. 64 of the Code (Paris and Montreal editions) which says that in such a case the first author who adopts the name in one sense must be followed. For these reasons we propose to follow established custom, which is to accept Usteria Willdenow.

Our choice is therefore to give Cothenius priority over Medikus and we hope that this choice will be followed until further evidence to the contrary is brought forward.

We may perhaps add one more note on the history of the publication of Usteria Willdenow. The genus was first described, but not named, by Willdenow in a letter dated 7 Nov. 1789 in Römer et Usteri, Magazin für die Botanik 8: 151. Apr (?) 1790. "Vor einigen Tagen untersuchte ich einige africanische Pflanzen .... fand ich ein sehr merkwürdiges neues Genus ....". He gives the characters and states that he is going to publish this new genus in the Schriften der Berlinischen Gesellschaft NaturforschenderFreunde. In the meantime, however, the generic name Usteria ' 'Vsteria') was published for it in Cothenius' book on p. 1 in a note saying "Com. municata ab amicissimo Doctore Willdenow". Since Cothenius died on 5 January 1789, and since Willdenow discovered Usteria only in November 1789 it is clear that the name should be attributed to Willdenow alone. The circumstantial evidence quoted in this paper makes it also probable that it was indeed Willdenow who edited Cothenius' manuscript and who inserted the 1789 genera and the Usteria paragraph.

Christian Andreas Cothenius was born on 14. February 1708 in Anklam; he died in Berlin on 5 January 1789. He was trained to be a medical doctor, became "Hofrath" of king Frederic William I and "Leibarzt" (court physician) of king Frederic (II) the Great in Potsdam. He published very little: a few medical treatises and in botany only the Dispositio.

We are very grateful to $\mathrm{Mr}$ J. E. Dandy and Mr R. Ross for critically reading our manuscript and for the verification of certain details. 